\title{
Editorial
}

\section{Editorial da Revista Ensaio 52}

A Revista Ensaio - Avaliação e Políticas Públicas em Educação, em seu qüinquagésimo segundo número, oferece a seu público leitor uma considerável colaboração, advinda de estudos e pesquisas realizadas por aqueles que têm como centro de suas investigações, a avaliação, em enfoques diversificados, bem como as políticas públicas, em diferentes níveis, temas de abrangência inesgotável.

Nos textos que compõem este número, são abordados assuntos que envolvem o Provão, o ENADE, o Sistema Educacional Chileno, a Auto-avaliação Institucional, os Conselhos Municipais de Educação do Rio Grande do Sul, a Evasão Escolar, a Responsabilidade Social e a Rede Municipal de Recife. Considerando-se a diversificação das menções anteriores e sua importância para uma maior e melhor compreensão do momento vivido pela educação em nosso país, acreditamos na colaboração que esta Revista está trazendo a seus leitores.

Robert Evan Verhine, Lys Maria Vinhaes Dantas e José Francisco Soares, no artigo intitulado "Do Provão ao ENADE: uma análise comparativa dos exames nacionais utilizados no Ensino Superior Brasileiro", procedem a um estudo que compara os mencionados exames, identificando diferenças e similaridades entre eles.

No artigo, "Desafíos del fortalecimiento de la gestión de los gobiernos subnacionales chilenos en Educación", Sebastián Donoso Díaz e Víctor Cancino Cancino revisam a noção de Estado e Governo aplicada ao caso chileno, uma vez que os processos de descentralização representam o marco, onde se assentam os desafios da gestão dos governos subnacionais, no Chile.

Com o propósito de apresentar algumas reflexões sobre a rede de relações, que se configuram nas dez dimensões abordadas pelo Sistema Nacional de Avaliação do Ensino Superior - SINAES, Lina Cardoso Nunes, no artigo "As dimensões da auto-avaliação institucional: tecendo redes de redes", estabelece relações entre essas dimensões, daí surgindo redes de pessoas, idéias, acontecimentos e práticas veiculadas no interior da universidade. 
Flávia Obino Corrêa Werle, no artigo "Gestão da educação municipal: composição dos Conselhos Municipais de Educação no Rio Grande do Sul", apresenta um estudo centrado na composição desses Conselhos, tendo em vista o que preconiza a legislação que os institui. A análise desenvolvida leva em conta os textos legais e a descrição da metodologia utilizada na pesquisa.

Abordando o fenômeno da evasão discente, em Cursos de Graduação da UFC, no texto "Opiniões de docentes e de coordenadores acerca do fenômeno da evasão discente dos cursos de graduação da Universidade Federal do Ceará", Wagner Bandeira Andriola, Cristiany Gomes Andriola e Cristiane Pascoal Moura tratam dessa temática desde a perspectiva de docentes e coordenadores.

Na sessão Página Aberta, Geraldo Caliman expõe um tema bastante atual, denominando-o "Estudantes em situação de risco e prevenção". O texto mostra a escola de nosso tempo e seu público: crianças e adolescentes de seguimentos sociais diversificados, cada um deles com sua história pessoal, que para alguns é regular e para outros é caracterizada por situações de risco, fracassos, desvantagens e sofrimentos.

A Pesquisa em Síntese nos traz a "Análise da metodologia de ensino de ciências nas escolas da rede municipal de Recife", investigação realizada por Kênio Erithon Cavalcante Lima e Simão Dias Vasconcelos junto a professores da rede, observando, entre outros aspectos, o uso do livro didático, as estratégias de ensino e a avaliação, bem como o desenvolvimento de atividades extraclasses.

Assim sendo, fica evidenciada a diversidade de temas contidos no presente número de nossa revista, todos oportunos e pertinentes à Área de Avaliação e Políticas Públicas em Educação, eixo central desta publicação. Eles, seguramente, despertarão em nosso público leitor $o$ interesse pelo aprofundamento e, inclusive, alguns questionamentos com relação aos mesmos, oriundos de sua leitura.

Carlos Alberto Serpa de Oliveira 